\title{
POTASSIUM AND NITROGEN FERTILIZER EXPERIMENT OF CELERY (APIUM GRAVEOLENS CONVAR. RAPACEUM) TEST PLANT IN 2018
}

\author{
Judit Petö ${ }^{1 *}$, Attila Hüvely ${ }^{1}$, Imre Cserni ${ }^{2}$ \\ ${ }^{1}$ Department of Agricultural Science, Faculty of Horticulture and Rural Development, John von Neumann \\ University, Kecskemét, Hungary \\ ${ }^{2}$ professor emeritus of the Faculty of Horticulture and Rural Development, John von Neumann University, \\ Kecskemét, Hungary \\ https://doi.org/10.47833/2020.2.AGR.040
}

\author{
Keywords: \\ Lysimeter growing pot \\ Sandy soil \\ Celery \\ Potassium fertilizer \\ Tuber mass
}

\section{Article history:}

Received 8 May 2020

Revised 18 May 2020

Accepted 25 May 2020

\begin{abstract}
This experiment was performed in 2018 in the internal study garden of John von Neumann University. Plants were grown in large lysimeter-type, large culture pots. Pots were filled with sandy soil, common in Kecskemét. Six groups of samples were made with different potassium and nitrogen containing fertilizer treatments.

In our experiment, in celery, satisfactorily supplied with potassium, half of the biomass weight was tuber, while the other half was root and leaf, in almost equal proportions. The highest root mass, 37\%, was shown by the control treatment.
\end{abstract}

\section{Introduction}

In Hungary, sandy soils account for almost $30 \%$, of which 615 thousand hectares are located in the area of the Danube-Tisza sand ridge $[1,2,3]$.

The soil of our experiment was a cover sand (Borbás desert) soil belonging to the shifting sand soil subtype. In terms of the texture of these soils, $16 \%$ is sand and $10 \%$ is sandy loam [4]. Their water, air and heat management are poor. They are genetically poor in organic and mineral colloids. Their structure is severely degraded. Only humus-rich sandy loam soils with a humus content above $1 \%$ have some structure.

The total potassium $(\mathrm{K})$ content of sandy soils is from 0.2 to $3.3 \%$, of which only a small part can be utilized for plants. Potassium is found in the form of $\mathrm{K}^{+}$ion in soil solution, on the surface of colloids (in the form of adsorbed exchangeable ion), in non-exchangeable form strongly bound to clay minerals and in crystal grids of primary potassium minerals [8, 9]. In addition to their low clay mineral content, their organic matter content is only $1.2-3 \%[6,7]$. It follows from the above that the K-supply capacity of our soils is low $[5,6,7]$ and can be considered poor.

An equilibrium is formed in the soil solution between the exchangeable and non-exchangeable $\mathrm{K}^{+}$ion content. However, potassium binding can hardly be expected on our sandy soils because of the low clay mineral content and thus the low level of selective binding $[5,6,10,11,12]$. In the nutrient supply of vegetable plants, it is important to follow that in which manner the nutrients are available to the plant in soluble form during the growing season, and at different stages of plant development $[13,14]$.

In plants, potassium remains in ionic form and may be mineralized from organic matter after the plants die. Therefore, only the presence of inorganic potassium in the soil is expected.

\footnotetext{
* Corresponding author. Tel.: +36 76517661

E-mail address: peto.judit@kvk.uni-neumann.hu
} 
In this lysimeter system, we have previously studied leached nutrients from the soil, involving potassium as well $[15,16,17,18,19,20,21]$. We have been carrying out pot experiments for decades with different vegetable and field crop test plant cultures using different types and amounts of fertilizer treatments. Organic-fertilized treatments were always set in the same culture vessels. The effect of potassium nutrient on crop elements was already studied in the previous year, also with tuberous celery test plant [18].

According to our previous experiment, as a result of increasing doses of nitrogen, $\mathrm{N}$ content of celery tubers increased significantly. In parallel, nitrogen showed a positive correlation with iron content, but it showed negative correlation with calcium and copper levels [18]. Nitrogen content of the soil also had a positive effect on the vitamin $C$ content. Our results show that organic fertilization on sandy soils, which increased the colloid content and improved the soil structure and water management, proved to be very favourable (humate effect).

Our results have been reported continuously in a number of forums since the 1990s [18, 19, 20]. In this experiment, a complex fertilizer, granular organic fertilizer, ammonium nitrate and potassium sulphate fertilizers were used in investigating the effect of nitrogen and potassium nutrients on celery crop.

\section{Materials and methods}

The present experiments were carried out in the inner demonstration garden of the Faculty of Horticulture and Rural Development of John von Neumann University, in 2018. Lysimeter-type pots with $0.3 \mathrm{~m}^{2}$ surface and drain water outlet, were sunk into the ground. The soil of the experiment was shifting sand soil belonging to the main type of frame soils. In the randomized block experiment, there were six treatments in four replicates. Rain-like irrigation was used. Two series of the pots were lifted with $50 \mathrm{~cm}$, and drain water was collected through a connected pipe. For the characterization of soil properties and nutrient content, we collected soil samples from the pots prior the beginning of the experiment (with the exception of organic-fertilized pots). The depth of sampling was $0-30 \mathrm{~cm}$.

Soil samples were tested prior the experiment in the accredited Soil and Plant Testing Laboratory in the Faculty of Horticulture and Rural Development, John von Neumann University.

Soil tests were made by standard methods. Soil test results are shown in Table 1.

Table 1. Soil physical and main nutrient chemical properties of growing pot soil samples

\begin{tabular}{|c|c|c|c|c|c|c|c|c|}
\hline $\mathrm{pH}\left(\mathrm{H}_{2} \mathrm{O}\right)$ & $\mathrm{pH}(\mathrm{KCl})$ & $\begin{array}{c}\text { Plasticity } \\
\mathrm{K}_{\mathrm{A}}\end{array}$ & $\begin{array}{c}\text { Soluble } \\
\text { salt }\end{array}$ & $\mathrm{CaCO}_{3}$ & $\mathrm{H} \%$ & $\left(\mathrm{NO}_{3}-\mathrm{NO}_{2}\right)-\mathrm{N}$ & $\mathrm{AL}-\mathrm{P}_{2} \mathrm{O}_{5}$ & $\mathrm{AL}-\mathrm{K}_{2} \mathrm{O}$ \\
\hline- & - & - & $\mathrm{m} / \mathrm{m} \%$ & $\mathrm{~m} / \mathrm{m} \%$ & $\mathrm{~m} / \mathrm{m} \%$ & $\mathrm{mg} / \mathrm{kg}$ & $\mathrm{mg} / \mathrm{kg}$ & $\mathrm{mg} / \mathrm{kg}$ \\
\hline 7.58 & 7.42 & 27 & $<0.02$ & 1.41 & 0.65 & 3.04 & 330.4 & 83.7 \\
\hline
\end{tabular}

According to the soil test results, the $\mathrm{pH}$ was neutral and had a sand mechanical structure. Organic matter content was low, and in correlation with it, $\mathrm{N}$ content was low as well. $\mathrm{P}$ and $\mathrm{K}$ supply was in the medium range.

The fertilization protocol of the applied six treatments are shown in Table 2. 
Table 2. Treatment protocol of the experiment

\begin{tabular}{|c|c|c|c|c|c|c|c|c|c|c|c|c|c|}
\hline \multirow{4}{*}{$\begin{array}{c}\text { Treat- } \\
\text { ment } \\
\text { No. }\end{array}$} & \multirow{4}{*}{$\begin{array}{l}\text { Treatment } \\
\text { code }\end{array}$} & \multicolumn{6}{|c|}{ Basic fertilizer } & \multirow{2}{*}{\multicolumn{3}{|c|}{$\begin{array}{l}\text { Basic }{ }^{*} \text { and head } \\
\text { fertilizer }\end{array}$}} & \multirow{2}{*}{\multicolumn{3}{|c|}{ Total }} \\
\hline & & \multicolumn{3}{|c|}{ NovaTec } & \multicolumn{3}{|c|}{ Orgevit } & & & & & & \\
\hline & & $\mathrm{N}$ & $\mathrm{P}_{2} \mathrm{O}_{5}$ & $\mathrm{~K}_{2} \mathrm{O}$ & $\mathrm{N}$ & $\mathrm{P}_{2} \mathrm{O}_{5}$ & $\mathrm{~K}_{2} \mathrm{O}$ & $\mathrm{N}$ & $\mathrm{P}_{2} \mathrm{O}_{5}$ & $\mathrm{~K}_{2} \mathrm{O}$ & $\mathrm{N}$ & $\mathrm{P}_{2} \mathrm{O}_{5}$ & $\mathrm{~K}_{2} \mathrm{O}$ \\
\hline & & $\mathrm{kg} / \mathrm{ha}$ & $\mathrm{kg} / \mathrm{ha}$ & $\mathrm{kg} / \mathrm{ha}$ & $\mathrm{kg} / \mathrm{ha}$ & $\mathrm{kg} / \mathrm{ha}$ & $\mathrm{kg} / \mathrm{ha}$ & $\mathrm{kg} / \mathrm{ha}$ & $\mathrm{kg} / \mathrm{ha}$ & $\mathrm{kg} / \mathrm{ha}$ & $\mathrm{kg} / \mathrm{ha}$ & $\mathrm{kg} / \mathrm{ha}$ & $\mathrm{kg} / \mathrm{ha}$ \\
\hline 1 & Control & & & & & & & & & & 0 & 0 & \\
\hline 2 & NT+Org & 72 & 48 & 96 & 80 & 50 & 46 & & & & 152 & 98 & 142 \\
\hline 3 & NT & 72 & 48 & 96 & & & & & & & 72 & 48 & 96 \\
\hline 4 & $\mathrm{NT}+\mathrm{K} 150$ & 72 & 48 & 96 & & & & & & $75^{\star}+75$ & 72 & 48 & 246 \\
\hline 5 & $\mathrm{NT}+\mathrm{N} 66+\mathrm{K} 150$ & 72 & 48 & 96 & & & & $33+33$ & & $75^{*}+75$ & 138 & 48 & 246 \\
\hline 6 & $\mathrm{NT}+\mathrm{N} 66+\mathrm{K} 300$ & 72 & 48 & 96 & & & & $33+33$ & & $150^{*}+150$ & 138 & 48 & 39 \\
\hline
\end{tabular}

NT= Nova Tec (classic), 12:8:16 (+3MgO+te): in $600 \mathrm{~kg} /$ ha dose, representing 72:48:96 N, $\mathrm{P}_{2} \mathrm{O}_{5}$ and $\mathrm{K}_{2} \mathrm{O}$.

Org = Orgevit, 4,0:2,5:2,3 in $2000 \mathrm{~kg} /$ ha dose, representing 80:50:46 N, $\mathrm{P}_{2} \mathrm{O}_{5}$ and $\mathrm{K}_{2} \mathrm{O}$.

$\mathrm{N}: \mathrm{NH}_{4} \mathrm{NO}_{3}(34 \%) 66 \mathrm{~kg} / \mathrm{ha} \mathrm{N}$, given in two equal doses, as head fertilizer.

$\mathrm{K}: \mathrm{K}_{2} \mathrm{SO}_{4}(50 \%) 150$ or $300 \mathrm{~kg} / \mathrm{ha} \mathrm{K}_{2} \mathrm{O}$, given in two equal doses, as basic and head fertilizer.

Test plant of the experiment was celery (Apium graveolens convar. rapaceum) (Figure 1.). Seedlings were planted in May 2018., in 5 plants/pot density.

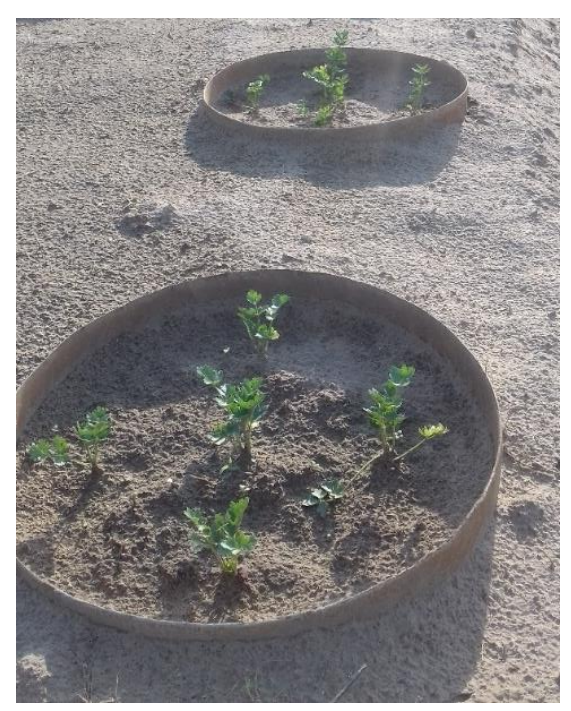

Figure 1. Celery test plants in the lysimeter pots in May 2018

The culture pots were kept weed-free by mechanical methods during the growing season. Irrigation was done with rain-like irrigation according to the needs of the plants. No plant protection was used, although powdery mildew infection revealed in all treatments. Harvesting was carried out at the end of the growing season, in a state of market value (22 October 2018). Total mass per pots were followed. Leaf, tuber and root mass yield per treatment and replication were also measured. The results were evaluated by variance analysis [22]. 


\section{Results}

Total biomass production of celery is shown in Figure 2. It can be clearly seen that the absolute zero treatment has a very low total mass yield due to the extremely high NPK deficiency. The yield of the NT + K150 treatment was almost the double. However, it is clear that the K surplus did not compensate for the $\mathrm{N}$ deficiency. Organic fertilization and treatments supplemented with extra nitrogen and potassium already yielded higher yields than the NT control that received the lowest amount of NPK. Orgevit treatment had a positive effect on the nutrient and water management of the sandy soil, coupled with some structural improvements.

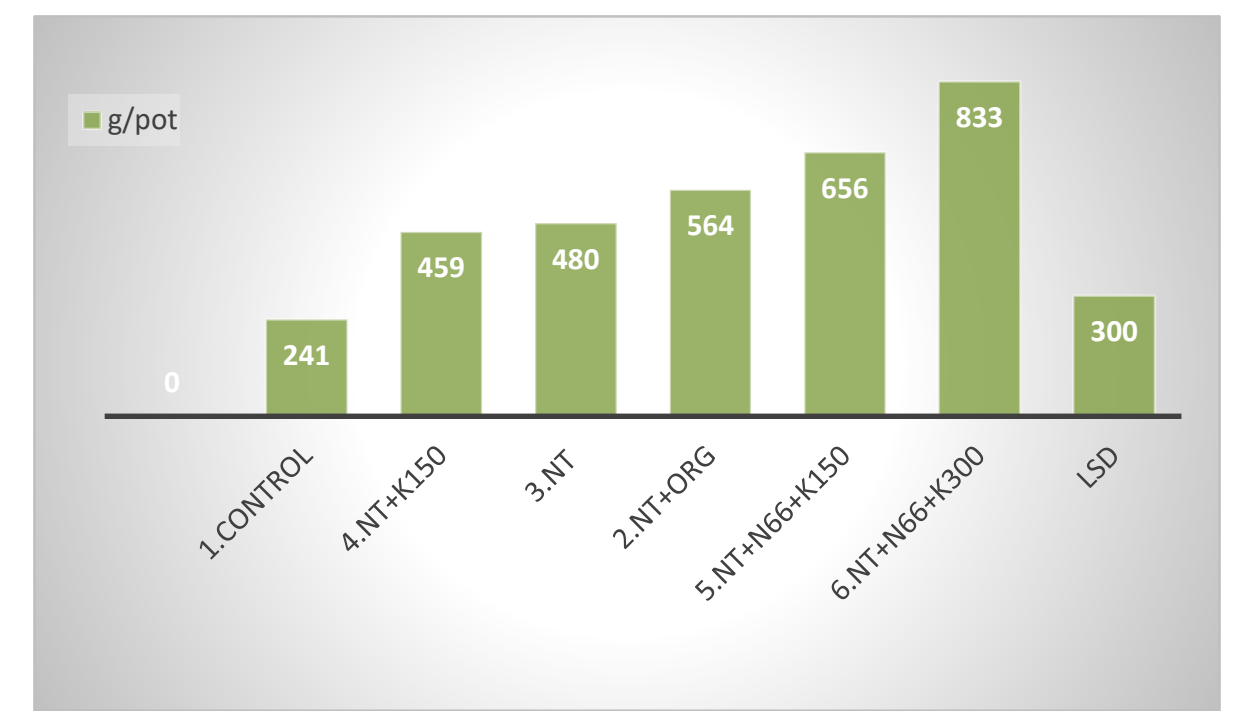

Figure 2. Total biomass production of celery plants after different treatments ( $g / p o t)$

NT (potassium control) and NT + K150 were hardly different. However, organic fertilizer treatment has already produced significantly higher biomass mass., Treatment 6 with the highest amount of fertilizer (NT + N66 + K300) produced significantly higher amount than NT (K control), with $95 \%$ safety.

The lowest tuber yield was got also in the absolute control treatment (Figure 3). Organic fertilizer and $\mathrm{N}+\mathrm{K}$ supplemented treatments produced significantly higher tuber mass, with $95 \%$ confidence.

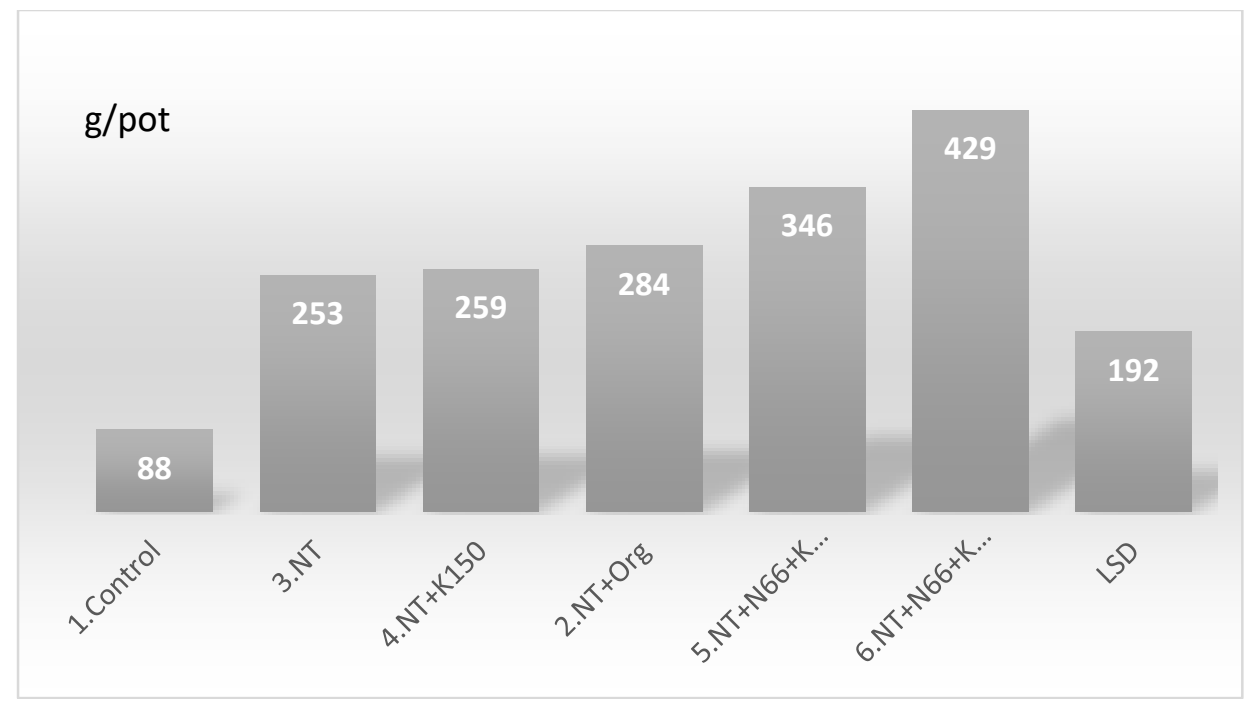

Figure 3. Average tuber mass after different treatments (g/pot) 
The weight of tubers per number of pieces in treatments (Figure 4) show that it was very small in the case of the control treatment $(21.9 \mathrm{~g} /$ piece $)$, while the potassium control treatment was already three times of that $(59.4 \mathrm{~g} /$ piece). NT basic fertilizer treatments supplemented with potassium and nitrogen plus potassium formed an average mass of 76.9-79.6 g/piece). Finally, organic fertilization and the treatments that received the highest amount of nutrients were resulted in the highest mass 87.3 - $95.3 \mathrm{~g} /$ piece.

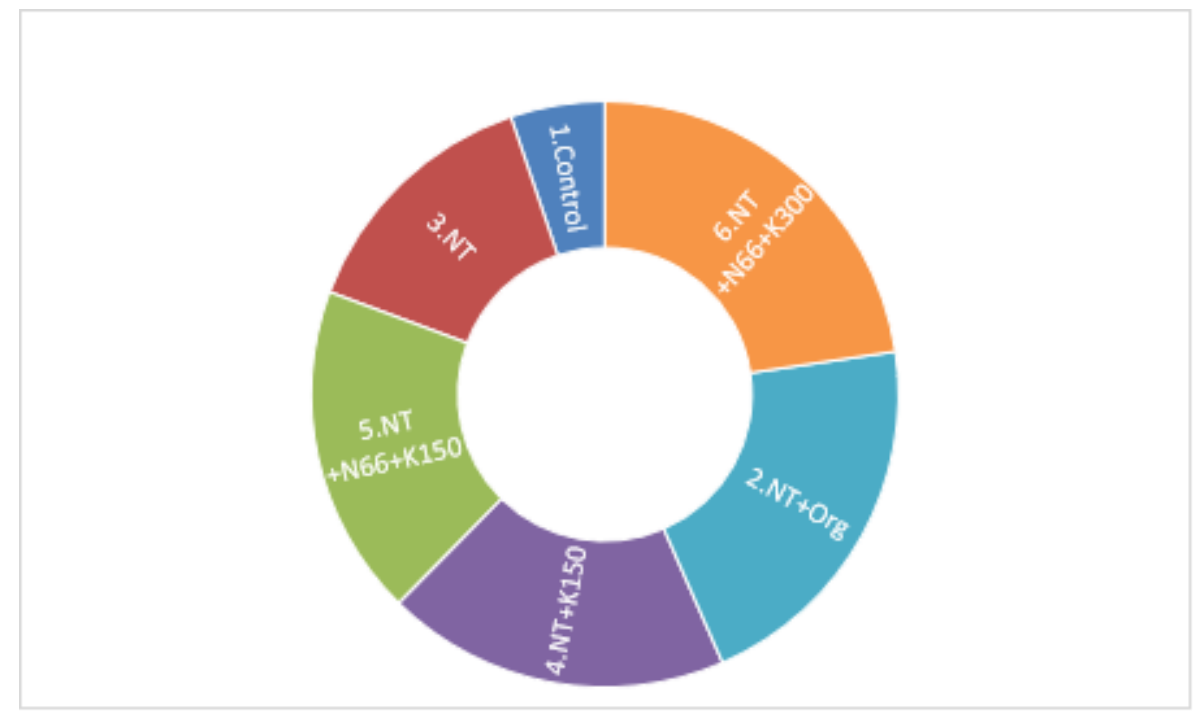

Figure 4. Average weight of celery tubers after different treatments (g/piece)

The results of the analysis of the crop parts show that the highest root mass was reached by the absolute zero control (Treatment 1, root ratio was 37\%) (Figure 5). This may be explained by the results of soil tests as the soil has a very low mineral nitrogen content: $\left(\mathrm{NO}_{2}-\mathrm{NO}_{3}\right)-\mathrm{N}$ was $3.04 \mathrm{mg} / \mathrm{kg}$ (Table 1). As a result, root growth was more intensive, probably meaning that larger root formation was required for higher food intake. The root was "looking for" the nutrients. In the other treatments, the root mass was much lower, it fluctuated between $23-26 \%$.

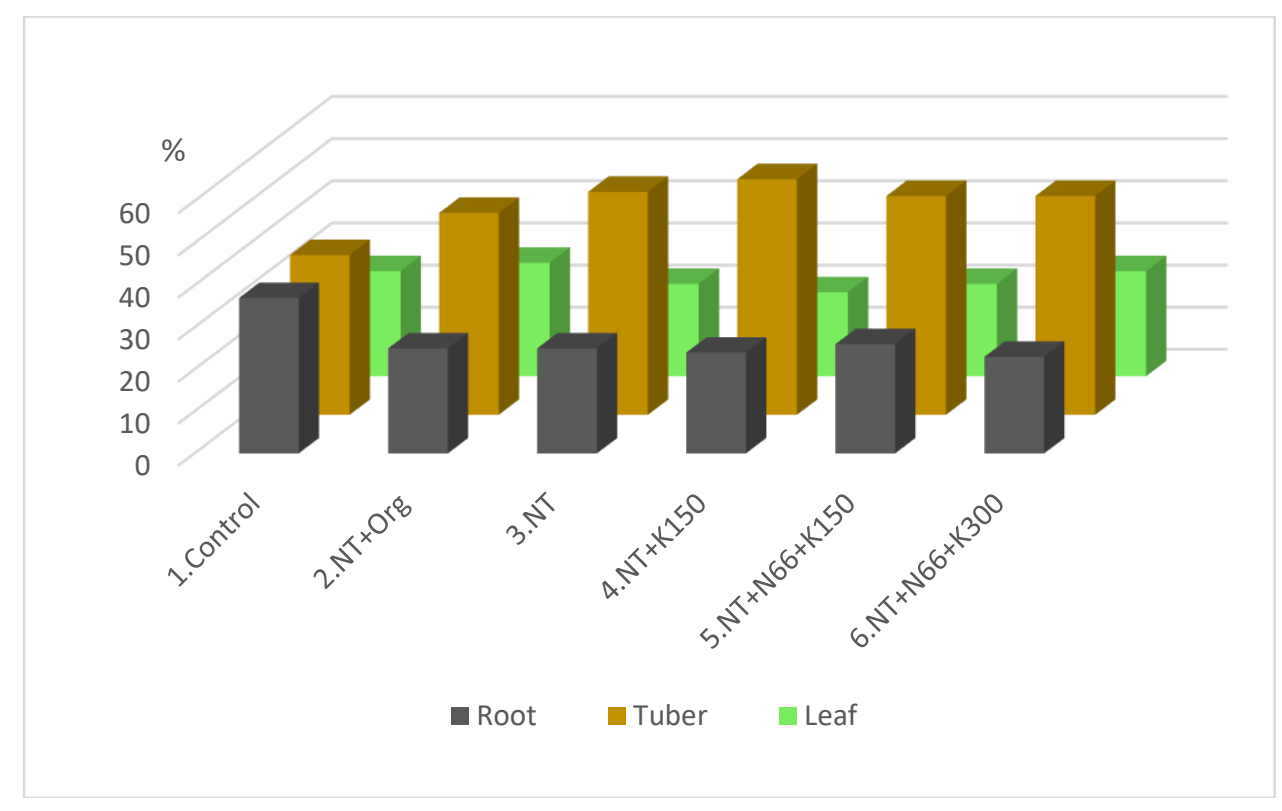

Figure 5. Percentage distribution of celery crop parts 
The highest tuber ratio in plants was obtained by $246 \mathrm{~kg} / \mathrm{ha} \mathrm{K}_{2} \mathrm{O}$ fertilizer (Treatment 4), it was $56 \%$. Treatments 5 and 6 , which received even more, plus nitrogen and potassium fertilizers, resulted a little bit lower, $52-52 \%$ tuber ratio. So, we find these fertilizer amounts excessive. The lowest tuber weight $(38 \%)$ was got by the unfertilized treatment and then by treatment with granular organic manure (48\%). This fact contradicts our previous experiment in the year 2017 in some respects [18]. This may be explained by that the granulated organic manure was mixed into the soil immediately before planting, and there was not enough time to decompose the organic matter, as organic manure has prolonged effect.

Leaf weight was the highest in the organic fertilizer treatment ( $27 \%$ of total plant mass), while the average of the fertilized treatments was only $22 \%$. This was also observed in our previous experiment [18].

When examining the average percentage of each crop element in the case of the control and treated pots, we observed that: in the absolute control plants, the ratio of leaf was $25 \%$, while the root and tuber weights were almost the same, $37 \%$ and $38 \%$, respectively. In contrast, in the case of fertilized treatments, the proportion of the leaf was almost the same as that of the control (23\%), but the root was only $25 \%$, and the tuber represented more than half of the total weight, it was $52 \%$ in the average (Figure 6).

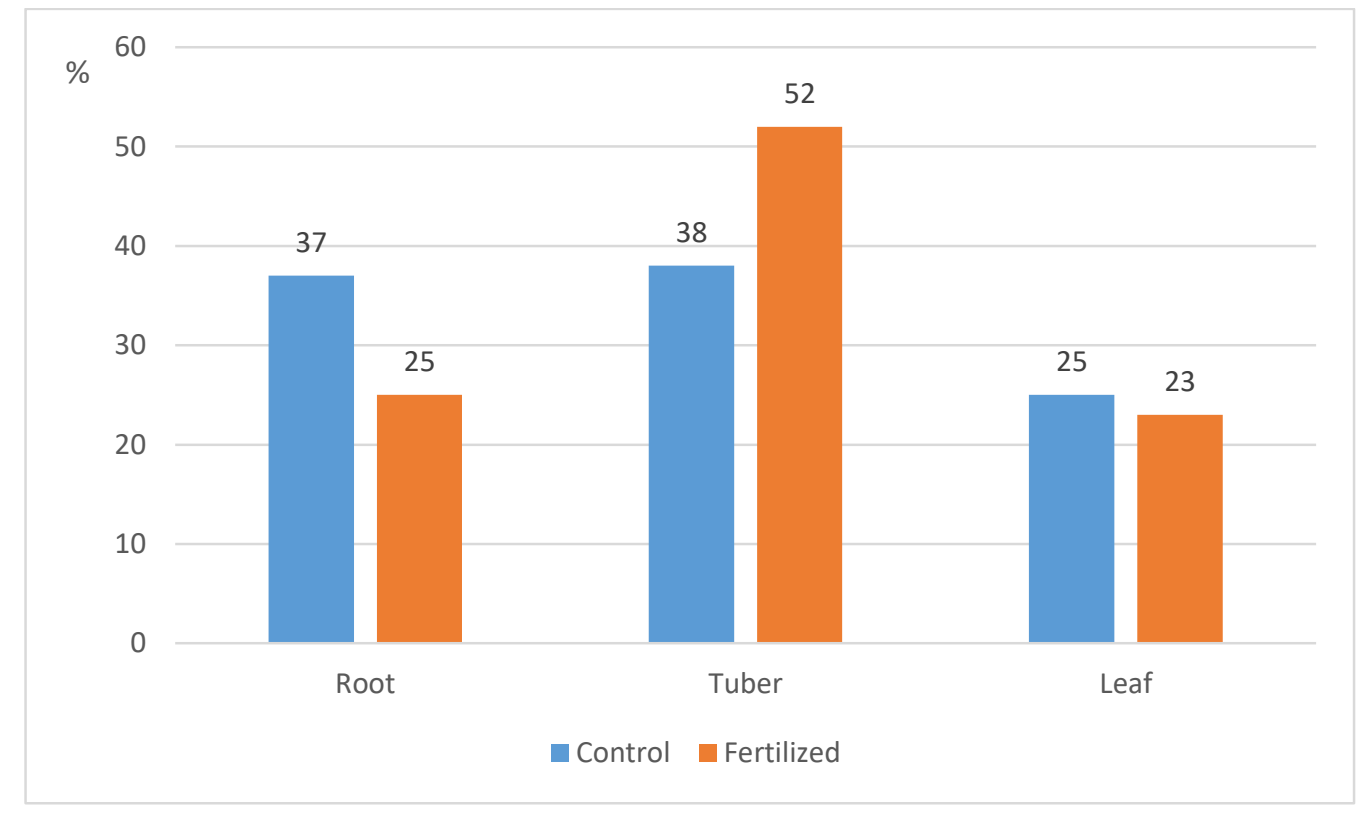

Figure 6. Ratio of different parts of celery to total plant weight (expressed in \%)

\section{Discussion}

It is known that the nutrient content of our sandy soils, especially their humus content, and their ability to provide nitrogen are extremely weak (Table 1). Total yield in field crops is determined by the amount of the nitrogen in many cases $[23,24,25]$. This is also the case for the vegetable crops.

At the beginning of the 21th century, based on our philosophy of "environmentally friendly nutrient management in open field vegetable production", our goal is not to increase the nutrient content of the soils at any rate, but to take better account of soil nutrient supply, plant nutrient demand, to avoid further load on the environment and achieve a good crop in an economical way [26].

Examining all the biomass weights, it can be stated that the weight of the crop was extremely small, which can be attributed primarily to powdery mildew infection during the growing season. 
From the soil test data, it can be seen that the mineral $\mathrm{N}$ content as well as the humus content of the soil of our experiment were extremely low, while the $A L-K_{2} \mathrm{O}$ content of our soil was in the medium range. On the other hand, the phosphorus content of the sandy soil fell into the category of very good nutrient supply as a result of the previous annual nutrient replenishment, which is also supported by Cserni's previous field experiments [27].

The treatments of our experiment were set up on the basis of the knowledge of the starting nutrient content of the soils, taking into account their background, so that the phosphorus content of the soil would rather stagnate in the experiment. Our results, in accordance with former studies, emphasize that the $\mathrm{K}$ surplus does not compensate for the $\mathrm{N}$ deficiency [5]. Leaf and tuber weight results were also compared with the results of the 2017 year [18].

The yields of the experiment, as in the case of all pot and micro-plot experiments, only allow to compare the results of the changes and proportions of the different treatments.

\section{Conclusion}

In summary, it can be said that in our experiment the most favorable effect of potassium nutrient on tuber weight was around $246 \mathrm{~kg} / \mathrm{ha} \mathrm{K}_{2} \mathrm{O}$ active ingredient. This dose already seems to be extremely large. The results call attention to the fact that root development is more intense in nutrient-poor soils (for "nutrient search"), which also results in more limited tuber formation. On the other hand, in nutrient-rich soils, especially those well supplied with potassium, half or more of the biomass mass is used for tuber formation, while the remainder, in almost equal proportions, is used for leaf and root formation.

\section{Acknowledgment}

Authors wish to thank for the support of the research carried out in the framework of the EFOP3.6.2-16-2017-00012 „Developing a functional, healthy and safe food product chain model from field to table in a thematic research network". The project is funded by the Hungarian State and the European Union, co-financed by the European Social Fund, and is part of the Széchenyi 2020 program.

Thanks to Csaba Szabó and the staff of the Soil and Plant Testing Laboratory for their help in the technical implementation of the experiments.

Rectification: Unfortunately, an incorrect data occurred in our 2017 experiment. In Table 1 the applied fertilizer treatment Nova-Tec $\mathrm{K}_{2} \mathrm{O} \mathrm{kg} / \mathrm{ha}$ is correctly $96 \mathrm{~kg} / \mathrm{ha}$ instead of $66 \mathrm{~kg} / \mathrm{ha}$. We therefore apologize to the reader [18].

\section{References}

[1] Stefanovits P. (1966): Hazánk homoktalajainak jellemzése. In: Antal-Egerszegi-Penyigei: Növénytermesztés homokon. Mezőgazda Kiadó. Budapest. pp. 9-22.

[2] Kádár I. (1999/a): Tápanyaggazdálkodás Magyarország homoktalajain. Internationa Potash Institute Basel /Switzerland, MTA TAKI., Budapest, Jász Nyomda- és Kiadó Kft. p. 34.

[3] Cserni I., Hüvely A., Pető J. (2019): Gumós zeller (Apium graveolens) trágyázási kísérlet. GRADUS 6. (2) pp. 116-121.

[4] Várallyay Gy. et.al. (1980): Magyarország termőhelyi adottságait meghatározó talajtani tényezők 1:100 000 méretarányú térképe. Agrokémia és Talajtan 29. pp. 149-156.

[5] Loch J., Nosticzius Á. (1992): Agrokémia és növényvédelmi kémia. Mezőgazda Kiadó. p. 399.

[6] Cserni I. (2000): Talajtan és agrokémia. Talajtan. Vol. I. KÉE KFK. Kecskemét. p. 206.

[7] Cserni I. (1968): Foszforhatás vizsgálata kukorica monokultúrában Duna-Tisza közi lepelhomok talajon. DunaTisza közi Mezőgazdasági Kutató Intézet Bulletinje. Kecskemét. (3) pp. 43-52.

[8] Stefanovits P. (1985): Clay mineral content of soils and fertilizer use. Agrokémia és Talajtan. 34. Suppl. pp. 6572.

[9] Füleky Gy. (1988): A talaj. Gondolat Zsebkönyvek. Budapest. p. 128.

[10] Nyle C. Bredy, Ray R.Weil (1999): The Nature and Properties of Soils. Canada Inc. Toronto. p. 881. ISBN-13: 978-0133254488 
[11] Füleky Gy. (1999): Növényi tápanyagok a talajban. In: Stefanovits - Filep - Füleky (1999): Talajtan. Mezőgazda. pp. 191-220.

[12] Kádár I. (1999/b): Kálium és jelentősége Magyarországon. International Potash Institute Basel/Switzerand, MTA TAKI., Budapest, Jász Nyomda- és Kiadó Kft. p. 32.

[13] Terbe I. (1991): Fólia alatti zöldségtermesztés. Mg-i Kiadó Kft. Budapest. p 74.

[14] Tölgyesi Gy. (1992): Trágyázás kertészetekben. Budapest. Agricola 103. p.

[15] Cserni I., Végh K., Füleki Gy. (2000): Tápelemek modellezése és mérése a talajban zöldségnövények alatt. Kutatási zárójelentés a T023348 OTKA témáról 1997-1999. Kézirat. 50. p.

[16] Cserni I., Kovács N., Zana S.-né, Borsné Pető J. (2003): Az elemek (N,P,K) mobilitása homoktalajon. In: Nagyné Fehér I.(szerk.) II. Erdei Ferenc Tudományos Konferencia: 2003.augusztus 28-29., Kecskemét. pp. 277-281.

[17] Cserni I., N. Kovács, A. Zana, J. Borsné Pető (2004): The Migration of Elements (NPK) in Sandy Soil. III. AlpsAdria Scientific Workshop, Dubrovnik, 1-6 March 2004. pp. 30-34.

[18] Cserni I. ,Hüvely A., Pető J. (2019): Gumós zeller (Apium graveolens convar. rapaceum) kálium trágyázási kísérlet. GRADUS 6:(1) pp. 219-226.

[19] Cserni I., Pető J., Hüvely A. (2015): A zeller növekedésének és egyes értékmérő paramétereinek vizsgálata, GRADUS 2:(2) pp. 236-241.

[20] Cserni I., Pető J., Hüvely A. (2017): Homoktalajok tápanyag-tartalma a tápanyag-ellátás függvényében, Talajvédelem 25 (különszám) pp. 357-362.

[21] Petö J., A. Hüvely, I. Cserni (2014): Plantation programs and their observations in the South-eastern Hungarian region. Proceedings of TEAM 2014 6th International Scientific and Expert Conference of the International TEAM Society 6(1) pp. 78-80. 10-11th November 2014, ISBN 978-615-5192-22-7

[22] Sváb J. (1973): Biometriai módszerek a kutatásban. Mezőgazdasági Kiadó.Budapest. 511.p.

[23] Bauer F. (1976): Növénytermesztés és tápanyag-gazdálkodás Duna-Tisza közi homoktalajokon. Akadémiai doktori értekezés. Kecskemét. 193. p.

[24] Bauer F.- Cserni I. (1993): A Duna-Tisza közi homokhátság mezőgazdasági hasznosításának kérdései. A Nyírség mezőgazdaság-fejlesztésének lehetőségei és távlatai című Tudományos Ülés. Nyíregyháza. 1993. szept. 21. pp. 25-28.

[25] Cserni I. - Bauer F. (1998): A kecskeméti homokkutatás múltja, jelene és jövője. Az MTA Talajtani és Agrokémiai Bizottsága c. tudományos találkozas. In: Cserni Imre (szerk). Homoktalajok hasznosításának időszerü kérdései a hazai homokkutatások tükrében. Kecskemét, 1997. aug. 28. KÉE KFK kiadványa pp. 35-44.

[26] Terbe I.- Csathó P. (2004): Környezetkímélő tápanyag-gazdálkodás a szabadföldi Zöldségtermesztésben. Budapesti Corvinus Egyetem Kertészettudományi Kar, Zöldség- és Gombatermesztési Tanszék, MTA Talajtani és Agrokémiai Kutatóintézet Budapest. 50 p.

[27] Cserni, I. (1983): A talaj AL-oldható foszfortartalmának alakulása évenkénti és feltöltő mütrágyázás esetén lepelhomok talajon. Agrokémia és Talajtan. 32:1-2 pp.97-119. 